\title{
ZAPOBIEGANIE PODWÓJNEMU OPODATKOWANIU DOCHODÓW Z PRACY NAJEMNEJ W KONTEKŚCIE UNIJNEJ SWOBODY PRZEPŁYWU PRACOWNIKÓW
}

\section{WSTĘP}

Postępująca globalizacja sprawiła, iż podwójne opodatkowanie w sensie prawnym znalazło się w centrum zainteresowania nie tylko podmiotów publicznych, ale także przedsiębiorców - coraz częściej przybierających międzynarodową szatę. Nowe możliwości kooperacji prywatnych podmiotów, podlegających jurysdykcjom różnych suwerennych władz, w tym jurysdykcjom podatkowym, oznaczają jednocześnie postawienie nowych wyzwań przed zagadnieniem gospodarowania kapitałem ludzkim. Obciążenia podatkowe nałożone na pracowników najemnych, nie są bowiem transparentne przy kształtowaniu polityk zatrudnienia przez przedsiębiorców. Omawiana problematyka uwidacznia się w szczególności wówczas, gdy obciążenie podatkowe staje się nadmierne - nie jako przejaw zbytniego fiskalizmu krajowego legislatora, ale przede wszystkim jako efekt skutecznego wystosowywania przez różne, nawet liberalne, jurysdykcje podatkowe roszczeń dotyczących podatków podobnego rodzaju wobec tego samego podatnika, w odniesieniu do tego samego stanu faktycznego, za ten sam okres. Niniejsza praca stanowi asumpt do zarysowania znaczenia unijnej swobody przepływu pracowników w powstawaniu zjawiska podwójnego opodatkowania dochodów osiąganych z pracy najemnej, a także wskazania na wypracowywane na gruncie międzynarodowego prawa podatkowego metody jemu przeciwdziałające.

* Student, Uniwersytet Łódzki, stażysta w Departamencie Doradztwa Podatkowego i Prawnego Kancelarii Prawno-Podatkowej Mariański Group. 


\section{MECHANIZM POWSTAWANIA PODWÓJNEGO OPODATKOWANIA W SENSIE PRAWNYM}

Uprawnienie do nakładania podatków, stanowiąc element suwerenności państwowej, nie wypływa z żadnego innego, zewnętrznego porządku prawnego ${ }^{1}$. W tym kontekście dopuszczalne jest opodatkowywanie stanów faktycznych mających miejsce nie tylko na terytorium danego kraju, ale i poza nim, o ile tylko istnieje racjonalna więź łącząca podatnika z suwerenną władzą ${ }^{2}$. Zupełnie wystarczające dla przypisania łącznikowi waloru racjonalności, jest przy tym, jak na gruncie polskiej ustawy o podatku dochodowym od osób fizycznych ${ }^{3}$, istnienie na terenie Rzeczypospolitej Polskiej centrum interesów osobistych, także jeśli podatnik nie ma obywatelstwa polskiego i nie przebywa w Polsce ani jednego dnia w roku4 ${ }^{4}$. Tak szeroka definicja rezydenta pozostaje zgodna z zasadami wypracowanymi na gruncie prawa międzynarodowego - zgodnie bowiem $z$ utrwalonym poglądem w literaturze, każde państwo ma daleko idącą autonomię $w$ określaniu materialnych i terytorialnych przesłanek obowiązku podatkowego, wynikającą wprost z zasady suwerennej równości państw ${ }^{5}$.

Powszechnie stosuje się równolegle dwie zasady przy wyznaczaniu zakresu roszczeń podatkowych: zasadę rezydencji oraz zasadę źródła ${ }^{6}$. Na gruncie bezpośrednich podatków dochodowych, zasada rezydencji polega na opodatkowaniu wszelkich dochodów podmiotów uznanych za rezydentów, bez względu na miejsce ich osiągnięcia. Zasada źródła z kolei odwołuje się do kryterium miejsca powstania dochodu - jeśli dochód powstał na terytorium danego państwa, powstanie obowiązek podatkowy, uregulowany przepisami tego $\mathrm{kraju}^{7}$. Wskazane zasady są przeważnie stosowane równolegle. Takie działania większości aktorów społeczności międzynarodowej, w sposób naturalny i logiczny prowadzą do równoczesnego nałożenia przez dwie autonomiczne władze podatkowe, podatku podobnego rodzaju, na tego samego podatnika, za ten sam okres, w odniesieniu do tego samego przedmiotu - powstania

1 Tak np. P. Selera, Międzynarodowe i unijne prawo podatkowe w kontekście opodatkowania przedsiębiorstw, Warszawa 2010, s. 55.

2 A. Biegalski, Międzynarodowe podwójne opodatkowanie, [w:] B. Brzeziński, Model konwencji OECD. Komentarz, s. 47.

3 Ustawa z dnia 26 lipca 1991 r. o podatku dochodowym od osób fizycznych, tekst jedn. Dz.U. z 2012 r., poz. 361, z późn. zm., zw. dalej: u.p.d.o.f.

4 M. Taborska, T. Kret, Rezydencja (miejsce zamieszkania lub siedziba), [w:] J. Zasiewska, A. Oktawiec, J. Chorązka, Umowy o unikaniu podwójnego opodatkowania. Komentarz, Warszawa 2011, s. 71.

5 J. Fiszer, Międzynarodowe podwójne opodatkowanie (problemy definicji), „Państwo i Prawo” 1990, nr 3, s. 68.

6 J. Banach, Polskie umowy o unikaniu podwójnego opodatkowania, Warszawa 2000, s. 56.

7 K. Budasz, W. Komer, Umowy o unikaniu podwójnego opodatkowania. Opodatkowanie płatności do odbiorców zagranicznych, Warszawa 2012, s. 13. 
zjawiska podwójnego opodatkowania w sensie prawnym ${ }^{8}$. Wówczas podatnik uznany za rezydenta jednego państwa, będzie podlegał jednocześnie nieograniczonemu obowiązkowi podatkowemu (od całości swoich dochodów) w państwie rezydencji oraz przeważnie ograniczonemu obowiązkowi podatkowemu w drugiej jurysdykcji - państwie źródła. W ten sposób dojdzie do skutecznego wystosowywania roszczeń wobec podatnika przez obie jurysdykcje i zagrożenia dwukrotnym pobraniem podatku podobnego rodzaju, mającym za przedmiot ten sam stan faktyczny, od tego samego podatnika, za ten sam okres.

Mimo że uprawnienie do nakładania podatków na stany faktyczne zachodzące poza terytorium danego państwa zostało bezdyskusyjnie przyznane przez prawo międzynarodowe suwerennym podmiotom, zjawisko podwójnego opodatkowania oceniane jest negatywnie. Hamuje bowiem rozwój gospodarczy i z tej przyczyny dążenie do jego wyeliminowania jest w interesie nie tylko podatników, ale i członków społeczności międzynarodowej ${ }^{9}$. Wobec powyższego powstała konieczność aplikowania metod zmierzających do wyeliminowania zjawiska podwójnego opodatkowania w sensie prawnym. Jest to działanie niezwykle istotne w dobie powszechnego korzystania z unijnej swobody przepływu pracowników, która przez niedoskonałe uregulowania podatkowe, może - zdaniem Autora - stać się niemającą odzwierciedlenia w rzeczywistości ideą.

\section{SWOBODA PRZEPŁYWU PRACOWNIKÓW JAKO CZYNNIK SPRZYJAJACCY POWSTAWANIU ZJAWISKA PODWÓJNEGO OPODATKOWANIA}

Niekwestionowaną wartością, na której opiera się Unia Europejska, jest swobodny przepływ osób. Swoboda migracji została uregulowana nie tylko na gruncie Traktatu o Funkcjonowaniu Unii Europejskiej ${ }^{10}$, ale także w artykule 45 Karty Praw Podstawowych ${ }^{11}$. Stosownie do dyspozycji wskazanego przepisu, każdy obywatel Unii ma prawo do swobodnego przemieszczenia się i przebywania na terytorium Państw Członkowskich. Rodzajem swobody migracji, jest swobodny przepływ pracowników. Artykuł 15 Karty Praw Podstawowych zapewnia każdemu obywatelowi Unii swobodę

$8 \mathrm{Na}$ takie cechy podwójnego opodatkowania w sensie prawnym wskazuje J. Fiszer, Międzynarodowe..., s. 72.

9 Jako przykład skutków braku działań podejmowanych dla wyeliminowania zjawiska podwójnego opodatkowania wskazuje się poziom gospodarki Libii oraz Kuby; zob. J. Banach, Polskie umowy..., s. 58.

10 Zob. Traktat o Funkcjonowaniu Unii Europejskiej, wersja skonsolidowana, Tytuł IV: Swobodny Przepływ osób, usług i kapitału, Rozdział 1: Pracownicy, Dz.Urz. UE z 30 marca 2010 r., Nr C 83.

11 Dz.Urz. UE. z 2007 r., Nr C 303 z późń. zm. 
poszukiwania zatrudnienia, wykonywania pracy, korzystania z prawa przedsiębiorczości, a także świadczenia usług w każdym Państwie Członkowskim. Szereg aktów należących do prawa wtórnego konkretyzuje przy tym wyrażone w Traktacie postanowienia. Ustanowione mechanizmy mają zagwarantować nie tylko bierne tolerowanie obywateli innych Państw Członkowskich świadczących pracę na terytorium danego kraju, ale także zapewniać równe warunki traktowania takich pracowników oraz bezpośrednią współpracę zarówno pomiędzy centralnymi, jak i regionalnymi, służbami zatrudnienia poszczególnych krajów ${ }^{12}$.

Powyższe swobody przyznane obywatelom Unii Europejskiej, mają istotne znaczenie praktyczne. Szacuje się, iż na koniec 2012 roku, 2,8\% ogólnej populacji Unii Europejskiej przebywało w innym kraju, aniżeli ich miejsce urodzenia ${ }^{13}$. Oznacza to, że na przełomie lat 2012/2013 prawie półtora miliona osób korzystało z omawianej swobody ${ }^{14}$. W 2011 roku, co trzydziesta osoba świadcząca pracę na terenie Unii Europejskiej, pracowała w innym kraju aniżeli jej miejsce urodzenia ${ }^{15}$. Wśród ofert zatrudnienia powszechnie dostępnych w Internecie na wybranych, polskojęzycznych portalach, 16,5\% dotyczy zagranicznego świadczenia pracy ${ }^{16}$. Napływ do Hiszpanii obywateli Rumunii, spowodował zawieszenie obowiązywania wobec nich zasady swobodnego przepływu pracowników ${ }^{17}$. Przyczyniali się oni bowiem do zwiększania znacznej, przeszło dwudziestoprocentowej stopy bezrobocia. Choć tak restrykcyjny środek, jakim jest zawieszenie postanowień unijnego prawa wtórnego, konkretyzujących normy prawa pierwotnego, może być wprowadzony jedynie w nagłych i wyjątkowych przypadkach, Komisja nie uznała działania Hiszpanii za nieusprawiedliwione ${ }^{18}$.

Przedstawione dane wskazują na duże zainteresowanie obywateli Unii swobodnym przemieszczaniem się w celach zarobkowych. Swobodny przepływ osób, w tym pracowników, stanowi „podstawowe prawo pracowników i ich rodzin”19. To fundament prawa unijnego, a przez artykuł 91 Konstytucji Rzeczypospolitej Polskiej, także

12 Rozporządzenie Parlamentu Europejskiego i Rady (UE) nr 492/2011 z dnia 5 kwietnia 2011 r. w sprawie swobodnego przepływu pracowników wewnątrz Unii, Dz.Urz. UE z 27 maja 2011 r., Nr L 141, Preambuła, pkt 8.

13 European Commision, Zatrudnienie i rozwój społeczny w Europie 2013 [Employment and Social Developments in Europe 2013], Bruksela 2014, s. 284.

14 Na dzień 1 stycznia 2013 roku ludność Unii Europejskiej wynosiła 500306522 osoby. Dane za: EUROSTAT.

15 European Commision, Zatrudnienie i rozwój społeczny 2011 w Europie [Employment and Social Developments in Europe 2011], Bruksela 2012, s. 49.

16 Statystyki opracowane przez Autora. Portal joobs.pl deklaruje 5621 ofert pracy za granicą. Portal pracuj.pl przedstawia 28394 ofert na terenie Polski [dostęp: 1.11.2014].

17 Por. Decyzja Komisji z dnia 11 sierpnia 2011 r. w sprawie upoważnienia Hiszpanii do tymczasowego zawieszenia stosowania art. 1-6 Rozporządzenia Parlamentu Europejskiego i Rady (UE) nr 492/2011 w sprawie swobodnego przepływu pracowników wewnątrz Unii w odniesieniu do pracowników rumuńskich, Dz.Urz. UE z dnia 12 sierpnia 2011 r., Nr L 207.

18 Ibidem.

19 Rozporządzenie Parlamentu Europejskiego i Rady (UE) nr 492/2011 ..., Preambuła, pkt 4. 
prawa krajowego. Należąc do wolności powszechnie wykorzystywanych, nie pozostaje bez wpływu na gospodarowanie kapitałem ludzkim, przede wszystkim w aspekcie międzynarodowym. Należy także zwrócić uwagę na ugruntowaną w orzecznictwie Trybunału Sprawiedliwości Unii Europejskiej definicję pracownika. Trybunał wielokrotnie podkreślał, iż pojęcie to musi być rozumiane obiektywnie i autonomicznie w stosunku do definicji przyjmowanych na gruncie prawa krajowego - traktowane jest bowiem jako posiadające „a community meaning”20. Wedle przyjętego znaczenia, dla uznania danego stosunku prawnego za stosunek pracy, kluczowe jest kryterium świadczenia pracy za wynagrodzeniem ${ }^{21}$. Wynagrodzenie takie stanowi jednak atrakcyjny potencjalny przedmiot opodatkowania dla wielu suwerennych jurysdykcji. Postępująca globalizacja sprawiła, iż coraz częściej pracodawca korzysta z pracy świadczonej przez zagranicznych rezydentów, co uwidacznia się w szczególny sposób, przy poszukiwaniu specjalistów związanych z naukami ścisłymi²2. Kluczowy dla omawianej problematyki jest fakt, iż wszystkie osoby fizyczne objęte swobodnym przepływem pracowników, otrzymują ex definitione za swoje usługi wynagrodzenie. Nałożona na pracodawcę przez prawo rola płatnika zaliczek na podatek dochodowy od osób fizycznych, wymaga uwzględniania, przy opracowywaniu strategii gospodarowania kapitałem ludzkim, uwarunkowań międzynarodowego prawa podatkowego z zakresu unikania podwójnego opodatkowania. Także nadmierne obciążenie fiskalne - efekt występowania zjawiska podwójnego opodatkowania - może zniechęcać pracowników do podejmowania pracy za granicą, stanowiąc tym samym barierę w swobodnym przepływie pracowników.

\section{METODY ELIMINOWANIA PODWÓJNEGO OPODATKOWANIA W SENSIE PRAWNYM}

Wyeliminowaniu zjawiska podwójnego opodatkowania w sensie prawnym służą środki trojakiego rodzaju: jednostronne, dwustronne, wielostronne ${ }^{23}$. Środki jednostronne, zawarte w wyłącznie w prawie wewnętrznym, polegają na odstąpieniu przez daną jurysdykcję od wystosowywania wobec podatnika roszczeń podatkowych. Wprowadzane są bez koordynacji ze społecznością międzynarodową, co wskazuje

20 „Wspólnotowe znaczenie” [tłum. Autora], por. Wyrok Europejskiego Trybunału Sprawiedliwości a dnia 3 lipca 1986 roku, w sprawie Deborah Lawrie-Blum przeciwko Land Baden-Württemberg, C-66/85, European Court Reports 1986, s. 212.

21 Por. Wyrok Europejskiego Trybunału Sprawiedliwości w sprawie B.N.O. Walrave, L.J.N. Koch przeciwko Association Union cycliste internationale, Koninklijke Nederlandsche Wielren Unie i Federación Española Ciclismo, C-36/74, European Court Reports, 1974, s. 1405.

22 OECD Committee on Fiscal Affairs, Model Tax Convention on Income and on Capital, OECD 2010, s. C(15)-13.

23 Tak np. J. Banach, Polskie umowy..., s. 58. 
na ich jurydyczną niedoskonałość pod względem zapewnienia spójności międzynarodowego systemu podatkowego. Środki wielostronne, polegające na zawieraniu multilateralnych umów międzynarodowych, choć są skuteczną metodą unikania podwójnego opodatkowania - dotyczą bowiem szerokiego kręgu podmiotów - ze względu na występujące pomiędzy poszczególnymi państwami konflikty interesów, nie znajdują poparcia na forum międzynarodowym²4. Aktualnie najszerszym, i z tego względu najskuteczniejszym, sposobem eliminowania podwójnego opodatkowania jest zawieranie dwustronnych umów międzynarodowych, w których państwa dokonują podziału pomiędzy siebie roszczeń podatkowych. Polska zawarła aktualnie takie umowy z 91 Państwami bądź terytoriami zależnymi ${ }^{25}$. W literaturze podkreśla się, iż wszystkie zawarte przez Polskę umowy międzynarodowe o unikaniu podwójnego opodatkowania, zostały oparte na Modelowej Konwencji Organizacji Współpracy Gospodarczej i Rozwoju (OECD) ${ }^{26}$. Opracowany do Konwencji oficjalny komentarz, nie stanowiąc źródła prawa, jest powszechnie uwzględniany przy dokonywaniu wykładni umów międzynarodowych dotyczących unikania podwójnego opodatkowania, zawartych przez Polskę, zarówno przez orzecznictwo ${ }^{27}$, jak i organy administracji podatkowej28.

W wewnętrznym prawie polskim istnieje jednostronny środek służący eliminowaniu zjawiska podwójnego opodatkowania, mający zastosowanie m.in. wówczas, gdy osoba fizyczna będąca rezydentem Polski, osiąga dochód ze źródeł położonych w państwie, z którym nie zawarto umowy o unikaniu podwójnego opodatkowania ${ }^{29}$. Zastosowana metoda zwykłego kredytu podatkowego może być jednak skrajnie niekorzystna dla podatnika, o czym świadczy chociażby potrzeba renegocjacji niektórych umów międzynarodowych dotyczących podwójnego opodatkowania, mająca miejsce po przystąpieniu Polski do Unii Europejskiej. Stosowanie metody zwykłego kredytu podatkowego w odniesieniu do dochodów osiąganych z pracy najemnej w Wielkiej Brytanii i Irlandii, spowodowało ponadto konieczność uchwalenia specjalnej ustawy o abolicji podatkowej ${ }^{30}$, co także wskazuje na jurydyczną niedoskonałość tego typu klauzuli.

24 Z. Kukulski, Konwencja Modelowa OECD i Konwencja Modelowa ONZ w polskiej praktyce traktatowej, Warszawa 2015, s. 49.

25 Dane opublikowane na stronie internetowej Ministerstwa Finansów RP, http://www.finanse. mf.gov.pl [dostęp: 1.11.2014].

26 J. Banach, Polskie umowy..., s. 61.

27 Zob. Wyrok Naczelnego Sądu Administracyjnego z dnia 18 grudnia 2012, II FSK 28/12, publikowany w Centralnej Bazie Orzeczeń Sądów Administracyjnych, zwanej dalej: CBOSA.

28 Pismo Ministra Finansów z dnia 7 czerwca 2002 roku, PB7/033-0136-383/01/ck.

29 Z. Kukulski, Komentarz do art. 27 ustawy o podatku dochodowym od osób fizycznych, [w:] Nykiel W., Mariański A. (red.), Komentarz do ustawy o podatku dochodowym od osób fizycznych, Gdańsk 2014, s. 885.

30 Ibidem, s. 887. 


\section{STATUS POLSKIEGO REZYDENTA NA GRUNCIE USTAWY O PODATKU DOCHODOWYM OD OSÓB FIZYCZNYCH}

Łącznikiem rezydencji między polską jurysdykcją podatkową, a osobą fizyczną, na gruncie polskiej ustawy o podatku dochodowym od osób fizycznych, jest miejsce zamieszkania, które od 1 stycznia 2007 roku zostało zdefiniowane autonomicznie w stosunku do prawa cywilnego ${ }^{31}$. Stosownie do dyspozycji znowelizowanego art. 3 ust. 1a u.p.d.o.f., za mającą miejsce zamieszkania na terytorium Rzeczypospolitej Polskiej, uważa się osobę fizyczną, która posiada na terytorium RP ośrodek interesów życiowych lub przebywa na terytorium RP dłużej niż 183 dni w roku. Ośrodek interesów życiowych został zdefiniowany przez ustawodawcę jako centrum interesów osobistych lub gospodarczych. Tak daleko idące i sprzeczne z intuicją językową zdefiniowanie miejsca zamieszkania, skutkuje objęciem nieograniczonym obowiązkiem podatkowym niezwykle szerokiej kategorii osób. W odniesieniu do pierwszego kryterium ustalania spełnienia przesłanki posiadania miejsca zamieszkania - ośrodka interesów życiowych - ustawodawca posłużył się bowiem alternatywą przy pojęciach centrum interesów osobistych a także centrum interesów gospodarczych. Dla zilustrowania skutków wskazanej zmiany, można posłużyć się przykładem podatnika, który wyemigrował zarobkowo poza terytorium Rzeczypospolitej Polskiej (nastąpiła zmiana centrum interesów gospodarczych), dodatkowo zrzekając się obywatelstwa polskiego. Taka osoba fizyczna pozostanie polskim rezydentem, o ile tylko pozostawi w Polsce więzi natury osobistej na tyle silne, by uznać, iż posiada w kraju centrum interesów osobistych. Liberalne rozumienie tego pojęcia przez organy podatkowe stwarza zagrożenie, iż niezwykle szeroka kategoria podmiotów zostanie uznana za rezydentów Rzeczypospolitej Polskiej32, a w konsekwencji częściej dojdzie do stosowania regulacji dotyczących unikania podwójnego opodatkowania.

\section{OPODATKOWANIE DOCHODÓW Z PRACY NAJEMNEJ NA GRUNCIE KONWENCJI MODELOWEJ OECD}

Art. 15 Konwencji Modelowej OECD dotyczy rozdzielenia roszczeń podatkowych dotyczących dochodów uzyskiwanych z pracy najemnej. Stanowi on normę o charakterze generalnym wobec innych postanowień Konwencji, dotyczących dochodów

31 Ustawa z dnia 16 listopada 2006 r. o zmianie ustawy o podatku dochodowym od osób fizycznych oraz niektórych innych ustaw, Dz.U. z 2006 r., Nr 217, poz. 1588.

32 Organy administracji definiują centrum interesów osobistych jako wszelkie powiązania rodzinne, a nawet - aktywność społeczną, polityczną, kulturalną, obywatelską czy uprawianie hobby. Por. Interpretacja indywidualna Ministra Finansów z dnia 5 października 2012, IPPB4/415569/12-2/SP. 
z zarobkowej działalności. Należy przede wszystkim dokonać odróżnienia hipotezy artykułu 15 od m.in. wykonywania wolnych zawodów, działalności sportowców, nauczycieli akademickich, które także mogą być oparte o nawiązane stosunki pracy, jednak w takich przypadkach, zgodnie z zasadą lex specialis derogat legi generali, zastosowanie znajdą dyspozycje artykułów Konwencji o bardziej szczegółowych hipotezach ${ }^{33}$.

Konwencja Modelowa nie zawiera definicji pracy najemnej. W myśl pozostałych postanowień konwencji, z zakresu tego pojęcia należy wyłączyć w szczególności zyski przedsiębiorstw oraz wynagrodzenia funkcjonariuszy publicznych. Cechy pracy najemnej zostały pozytywnie wskazane w Komentarzu do Konwencji Modelowej. Zaliczono do nich wydawanie wiążących poleceń, dostarczanie niezbędnych materiałów, nakładanie kar dyscyplinarnych, oraz ustalanie planu pracy ${ }^{34}$. By uznać, że dany stosunek jest pracą najemną w rozumieniu Konwencji, kluczowe jest zatem przyznanie temu stosunkowi przymiotu odpowiedniego stopnia zależności i wykonywania pracy pod kierownictwem innego podmiotu. Takie wnioski znajdują potwierdzenie w literaturze dotyczącej konkretnych rozwiązań, wypracowywanych na gruncie poszczególnych umów zawieranych przez Rzeczpospolitą Polską ${ }^{35}$.

Zgodnie z zasadą wyrażoną w art. 15 ust. 1 Konwencji Modelowej, jeżeli praca jest wykonywana w państwie rezydencji podatnika, dochód może być opodatkowany wyłącznie w tym państwie. Jednakże jeżeli praca wykonywana jest na terytorium innej jurysdykcji, dochód ze świadczenia pracy może być opodatkowany także w państwie wykonywania pracy, a do rozdzielenia roszczeń podatkowych znajdą zastosowanie konkretne metody eliminowania podwójnego opodatkowania. Wśród wielu problemów interpretacyjnych powstałych na gruncie tego przepisu, warto zwrócić uwagę, w kontekście gospodarowania kapitałem ludzkim, na problem zdefiniowania pojęć miejsca wykonywania pracy, a także pojęcia wynagrodzenia. Przyjmuje się, iż praca jest wykonywana w miejscu, gdzie pracownik fizycznie przebywa w trakcie dokonywania czynności, za które otrzymuje wynagrodzenie ${ }^{36}$. Należy zatem uznać, iż przy takich formach świadczenia pracy jak telepraca, co do zasady decydujące będzie miejsce faktycznego przebywania pracownika. Wspomniane kryterium przysparza jednak licznych problemów w przypadku osób wykonujących pracę związaną z przemieszczeniem się pomiędzy terytoriami różnych podmiotów, np. zaangażowania w transport międzynarodowy.

33 M. Jamroży, Opodatkowanie na gruncie umów o unikaniu podwójnego opodatkowania, [w:] M. Jamroży, T. Major, Praca cudzoziemców w Polsce. Aspekty prawne, podatkowe i ubezpieczeniowe, Gdańsk 2012, s. 81.

34 OECD Committee on Fiscal Affairs, Model Tax Convention on Income and on Capital, OECD 2010, s. C(15)-10.

35 Zob. K. Kaczor, Art. 15. Praca najemna / Unselbstaendige Arbeit, [w:] A. Cloer, M. Jamroży (red.), Umowa o unikaniu podwójnego opodatkowania z Niemcami, Warszawa 2007, s. 314-315.

36 OECD Committee on Fiscal Affairs, Model Tax Convention on Income and on Capital, OECD 2010, s. C(15)-1. 
Pojęcie otrzymywanego za pracę wynagrodzenia należy rozumieć szeroko. Strony umowy posługują się bowiem na gruncie artykułu 15 Konwencji Modelowej, w odniesieniu do przedmiotu opodatkowania, pojęciem „pensje, płace i inne podobne wynagrodzenia, które osoba mająca miejsce zamieszkania w Umawiającym się Państwie otrzymuje za pracę najemną (...)" [podkr. A.T.]. Dopiero w zdaniu drugim wprowadzane jest pojęcie „wynagrodzenia”, rozumianego holistycznie. Wykładnia systemowa wewnętrzna wskazuje na synonimiczne posługiwanie się przez strony umowy tymi pojęciami. W zakresie hipotezy omawianego przepisu znajdą się więc także nieodpłatne świadczenia, co do opodatkowania, których tylko w zakresie prawa wewnętrznego powstają spory i nieścisłości37.

Zasadniczym wyjątkiem od zasady opodatkowania dochodu w państwie źródła, przy odliczeniu zapłaconego podatku od tego dochodu lub zwolnieniu tego dochodu w państwie rezydencji podatnika, jest stan faktyczny obwarowany trzema przesłankami. Po ich łącznym wystąpieniu dochód będzie mógł zostać opodatkowany wyłącznie w państwie rezydencji.

Pierwszą z omawianych przesłanek jest przebywanie przez podatnika w państwie świadczenia pracy nie dłużej niż 183 dni w okresie 12 miesięcy, rozpoczynających się i kończących w danym roku podatkowym. Przy obliczaniu tego okresu, należy brać pod uwagę dni fizycznej obecności pracownika w danym państwie, niezależnie od tego, czy miało to miejsce w dni wolne od pracy ${ }^{38}$. Zróżnicowano bowiem pojęcie wykonywania pracy, którym strony umowy posługują się w celu określenia zakresu przedmiotowego regulacji artykułu 15 Konwencji, od pojęcia przebywania, mającego znaczenie dla stosowania wyjątku określonego w ustępie drugim omawianego przepisu. Okres ten jest w polskiej praktyce traktatowej różnie określany. W umowie z Filipinami wynosi 120 dni ${ }^{39}$, podczas gdy w umowie zawartej z sąsiadującą Indonezją następuje powrót do zasady wyrażonej w Konwencji Modelowej - okresu 183 dniowego $^{40}$. Rozwiązanie takie nie jest więc spowodowane przyczynami geograficznymi i trudno znaleźć racjonalne uzasadnienie dla zrzeczenia się roszczeń podatkowych wobec niektórych kategorii pracowników.

Kolejnym warunkiem opodatkowania wynagrodzenia wyłączenie w państwie rezydencji, jest nieposiadanie przez pracodawcę wypłacającego wynagrodzenie, lub osoby działającej w jego imieniu, miejsca zamieszkania lub siedziby w państwie wykonywania pracy. Ostatnią przesłanką, która musi być spełniona, aby przedmiotowy dochód został opodatkowany w państwie źródła, a zwolniony w państwie rezydencji,

37 Por. np. wyrok Trybunału Konstytucyjnego z dnia 8 lipca 2014 r., K 7/13, Z.U. 2014/7A/69.

38 Ibidem, s. C(15)-2.

39 Umowa między Rządem Rzeczypospolitej Polskiej a Rządem Republiki Filipin w sprawie unikania podwójnego opodatkowania i zapobiegania uchylaniu się od opodatkowania w zakresie podatków od dochodu, Dz.U. z 1997 r., Nr 127, poz. 817.

40 Umowa między Rządem Rzeczypospolitej Polskiej a Rządem Republiki Indonezji w sprawie unikania podwójnego opodatkowania i zapobiegania uchylaniu się od opodatkowania w zakresie podatków od dochodu, Dz.U. z 1994 r., Nr 46, poz. 187. 
jest nieponoszenie ciężaru wynagrodzenia przez zakład albo stałą placówkę, którą pracodawca posiada w państwie świadczenia pracy ${ }^{41}$. Przy braku zatem znaczących związków pracodawcy z miejscem wykonywania pracy przez pracownika, i przy nieprzekroczeniu wskazanego każdorazowo w umowie okresu przebywania, dochód będzie opodatkowany wyłącznie w państwie rezydencji podatnika. Sytuacja taka ma powszechne zastosowanie w przypadku delegowania pracowników do ograniczonego w czasie świadczenia usług na rzecz struktur przedsiębiorstwa pracodawcy, które nie są zakładem w rozumieniu art. 5 Konwencji Modeloweje2, czy też w przypadku świadczenia pracy przez dziennikarzy wykonujących obowiązki służbowe poza krajem rezydencji oraz w przypadku kierowców w lądowym transporcie międzynarodowym.

W kontekście omawianej problematyki, należy także podkreślić szczególną regulację opodatkowania wynagrodzenia otrzymywanego za pracę najemną, wykonywaną na pokładzie statku morskiego, powietrznego w transporcie międzynarodowym, a także barki w żegludze śródlądowej. Wówczas dochód ten będzie mógł zostać opodatkowany w państwie, w którym znajduje się miejsce faktycznego zarządu przedsiębiorstwa. Niezwykle interesujące rozwiązanie przyjęto na gruncie umowy z Filipinami, w której zawarto regulację zupełnie uniezależniającą problematykę jurysdykcji właściwej do nałożenia podatku od miejsca zarządu przedsiębiorstwa. Wynagrodzenie będzie mogło zostać opodatkowane w państwie, w którym pracownik ma miejsce zamieszkania lub którego jest obywatelem ${ }^{43}$. W kontekście gospodarowania kapitałem ludzkim, zdaniem Autora, rozwiązanie ukonstytuowane ustępem 3 artykułu 15 Konwencji Modelowej jest korzystniejsze dla pracodawcy od rozwiązania przyjętego w umowie polsko-filipińskiej. Pozwala bowiem stosować jednolitą praktykę rozliczeń księgowych bez względu na obywatelstwo czy miejsce zamieszkania pracowników, a ponadto nie stwarza zagrożenia otrzymywania przez pracowników zróżnicowanego, w zależności od posiadanej rezydencji, wynagrodzenia netto. Wskazane rozwiązanie pozostaje także spójne z zasadą opodatkowania zysków osiąganych z eksploatacji statków morskich lub powietrznych, wyrażoną w art. 8 Konwencji Modelowej. Na gruncie ustępu 3 artykułu 15 Konwencji Modelowej, przy ustalaniu miejsca faktycznego zarządu przedsiębiorstwem (a więc jurysdykcji uprawnionej do opodatkowania uzyskanego dochodu) mogą być brane pod uwagę kryteria takie jak podmiot uprawniony do utrzymywania kontaktów służbowych, struktura hierarchii i organizacja przedsiębiorstwa. Wiedza o miejscu faktycznego zarządu może przy tym być zdobywana na podstawie takich okoliczności jak codzienna praktyka i podpisana umowa ${ }^{44}$.

41 Konwencja operuje pojęciami pierwszego i drugiego państwa. Pojęcie „drugie państwo”, w kontekście ust. 2 art. 15, powinno być, zdaniem Autora, odnoszone do państwa, w którym praca jest faktycznie wykonywana.

42 M. Jamroży, Opodatkowanie na gruncie umów..., s. 93.

43 Umowa między Rządem Rzeczypospolitej Polskiej a Rządem Republiki Filipin...

44 Por. Interpretacja indywidualna Ministra Finansów z dnia 3 października 2008 r., ITPB2/415-692/08/PS. 


\section{PODSUMOWANIE}

Korzystanie z pracy rezydentów obcych państw staje się coraz powszechniejsze - nie tylko w aspekcie wykorzystywania „pracowników przygranicznych” (Charakter tego pojęcia o wiele lepiej oddaje angielska wersja językowa „frontier workers" ${ }^{45}$ ), ale także osób przenoszących na stałe centrum swoich interesów ekonomicznych do innej jurysdykcji, przy jednoczesnym zachowaniu pewnych więzi z macierzystym państwem - osób będących podwójnymi rezydentami. Choć zjawisko migracji w celach zarobkowych występuje nie tylko na gruncie relacji pomiędzy Państwami Członkowskimi, swobody, na których opiera się Unia Europejska, zwiększają skalę występowania podwójnego opodatkowania dochodów osiąganych z pracy najemnej. Swobodne przepływy mają przy tym istotne znaczenie także dla Europejskiego Obszaru Gospodarczego. Ustanowiony „nowy porządek prawny w prawie międzynarodowym"46, wymaga także ustanowienia nowego porządku prawnego w zakresie przeciwdziałania podwójnemu opodatkowaniu. Właściwie niczym nieograniczona swoboda w decydowaniu przez państwo o definicji swojego rezydenta, pozwala bowiem na opodatkowanie dochodów osiąganych przez podmioty posiadające nawet niewielką więź z jurysdykcją wystosowującą roszczenia w stosunku do dochodu osiąganego poza jej terytorium. Wymusza to na suwerennych jurysdykcjach zawieranie umów dotyczących unikania podwójnego opodatkowania - nie zawsze rozdzielającego roszczenia podatkowe w sposób korzystny dla podmiotu świadczącego pracę. Subsydiarnie stosowana w Polsce jednostronna metoda zwykłego kredytu podatkowego, co zostało w niniejszym artykule zaznaczone, może być niekorzystna dla podatnika. Taki stan rzeczy może skutkować nie tylko ograniczeniem dorobku unijnego, jakim jest swobodny przepływ pracowników, ale również w sposób realny oddziaływać na zagadnienie gospodarowania kapitałem ludzkim, dla którego efektywności konieczne jest uwzględnianie obciążeń podatkowych. Świadczenie przez polskiego rezydenta pracy w państwie, z którym Polska nie posiada ratyfikowanej umowy o unikaniu podwójnego opodatkowania, albo gdy w takiej umowie w odniesieniu do zasady wyrażonej w art. 15 ust. 1 Konwencji Modelowej stosowana jest metoda zwykłego kredytu podatkowego, będzie w pewnych okolicznościach niekorzystne dla pracownika - istnieje bowiem ryzyko, iż otrzyma on niższe wynagrodzenie netto, aniżeli gdyby był rezydentem państwa świadczenia pracy.

Nieuregulowanie, także w praktyce traktatowej, charakteru „innych podobnych wynagrodzeń" stwarza liczne wątpliwości interpretacyjne ${ }^{47}$. Działania podejmowane

45 K. Vogel, Klaus Vogel on Double Taxation Conventions, London 1999, s. 926.

46 Europejski Trybunał Sprawiedliwości tymi słowami określił Europejską Wspólnotę Gospodarczą, uzasadniając bezpośredni skutek Traktatów. Por. Wyrok Europejskiego Trybunału Sprawiedliwości z dnia 5 lutego 1963 w sprawie van Gend \& Loos, 26/62.

47 Szerzej: J. Stolarek, Opodatkowanie dochodu z pracy najemnej, [w:] J. Zasiewska, A. Oktawiec, J. Chorązka (red.), Umowy o unikaniu..., s. 331. 
przez Polskę należy w tym zakresie ocenić negatywnie - oparcie się na Konwencji Modelowej, bez precyzowania jaki charakter dochodu jest przedmiotem umowy, stwarza kolejną niepewność w i tak budzącej wątpliwości regulacji prawnej. Na pozytywną ocenę zasługuje jednak ustanowienie zasady opodatkowania dochodu w państwie źródła, przy stosowaniu odpowiedniej metody eliminowania podwójnego opodatkowania. Nałożona na pracodawcę rola płatnika zaliczek na podatek dochodowy gwarantuje, iż dochód będzie, przynajmniej wstępnie, opodatkowany w państwie źródła. Występujące wyjątkowo opodatkowanie dochodu jedynie w państwie rezydencji pracownika - w wypadku gdy m.in. dochód będzie wypłacany przez pracodawcę niemającego siedziby, miejsca zamieszkania, czy nieposiadającego zakładu w państwie źródła - współgra ze wspomnianą rolą pracodawcy jako płatnika.

Rozwiązaniem zarówno problemu podwójnego opodatkowania w sensie prawnym, jak i wynikającego z niego zagadnienia dotyczącego nierównego traktowania pracowników, poprzez stosowanie kryterium rezydencji, byłoby oparcie się, przy wyznaczaniu zakresu jurysdykcji podatkowej każdego członka społeczności międzynarodowej, wyłącznie na zasadzie źródła. Wówczas dochód podlegałby opodatkowaniu wyłącznie w miejscu jego osiągnięcia. Jest to jednak postulat niemożliwy do osiągnięcia, z uwagi na konieczność zrzeczenia się uprawnień wynikających z suwerennej równości państw - wymagający zatem konsensusu obejmującego wszystkich aktorów sceny międzynarodowej. Wobec powyższego, należy pozytywnie ocenić praktykę zawierania bilateralnych umów międzynarodowych, opartych na Konwencji Modelowej OECD.

Konstrukcja rozdzielenia roszczeń dotyczących opodatkowania dochodów z pracy najemnej, polegająca na opodatkowaniu dochodu, co do zasady, w miejscu świadczenia pracy, przy zastosowaniu metody zwykłego kredytu podatkowego może pozostawać w sprzeczności z zasadą równego traktowania pracowników. Na gruncie umów międzynarodowych, w pewnych sytuacjach, pracownicy będą bowiem ponosili różny ciężar podatkowy, mimo świadczenia takiej samej pracy u tego samego podmiotu, a jedyną cechą ich różnicującą byłoby posiadanie statusu rezydenta innej jurysdykcji. Należy zatem postulować stosowanie w polskiej praktyce traktatowej, w odniesieniu do Państw Członkowskich Unii Europejskiej, metody wyłączenia w stosunku do dochodu z pracy najemnej. Sama zasada opodatkowania dochodu w miejscu świadczenia pracy zasługuje, zdaniem Autora, na aprobatę - na państwie faktycznego wykonywania pracy ciąży bowiem obowiązek zapewnienia odpowiedniej infrastruktury, służącej rozwojowi gospodarczemu czy zachowaniu porządku publicznego. Należy zatem uznać, iż celowe jest partycypowanie w tych wydatkach przez pracowników korzystających z efektów polityki fiskalnej państwa, w którym praca jest wykonywana.

\section{BIBLIOGRAFIA}

Banach J., Polskie umowy o unikaniu podwójnego opodatkowania, Warszawa 2000.

Bartosiewicz A., Kubacki R. (red.), PIT. Komentarz, Warszawa 2014.

Brzeziński B., Model konwencji OECD. Komentarz, Warszawa 2010. 
Budasz K., Komer W., Umowy o unikaniu podwójnego opodatkowania. Opodatkowanie płatności do odbiorców zagranicznych, Warszawa 2012.

Cloer A., Jamroży M. (red.), Umowa o unikaniu podwójnego opodatkowania z Niemcami, Warszawa 2007.

Dörre-Nowak D., Ochrona godności i innych dóbr osobistych pracownika, Wydawnictwo C.H. Beck, Warszawa 2005.

European Commision, Zatrudnienie i rozwój społeczny 2011 w Europie [Employment and Social Developments in Europe 2011], Bruksela 2012.

European Commision, Zatrudnienie i rozwój społeczny w Europie 2013 [Employment and Social Developments in Europe 2013], Bruksela 2014.

Fiszer J., Międzynarodowe podwójne opodatkowanie (problemy definicji), „Państwo i Prawo" 1990, nr 2.

Gardocki L., Prawo karne, Wydawnictwo C.H. Beck, Warszawa 2010.

Jamroży M., Major T., Praca cudzoziemców w Polsce. Aspekty prawne, podatkowe i ubezpieczeniowe, Gdańsk 2012.

Kmiecik-Baran K., Cieślak W., Bez zgody na przemoc w szkole i pracy, GWP, Gdańsk 2001.

Kukulski Z., Konwencja Modelowa OECD i Konwencja Modelowa ONZ w polskiej praktyce traktatowej, Warszawa 2015.

Mietzel G., Wprowadzenie do psychologii. Podstawowe zagadnienia, GWP, Gdańsk 2003.

Nykiel W., Mariański A. (red.), Komentarz do ustawy o podatku dochodowym od osób fizycznych, Gdańsk 2014.

OECD Committee on Fiscal Affairs, Model Tax Convention on Income and on Capital, OECD 2010.

Selera P., Międzynarodowe i unijne prawo podatkowe w kontekście opodatkowania przedsiębiorstw, Warszawa 2010.

Stelmach W., Ciemne strony kierowania, Placet, Warszawa 2005.

Vogel K., Klaus Vogel on Double Taxation Conventions, London 1999.

Wyciślok J., Umowa modelowa OECD. Konwencja Modelowa o podatku dochodowym i podatku od kapitału, Katowice 2000.

Zasiewska M., Oktawiec A., Chorązka J. (red.), Umowy o unikaniu podwójnego opodatkowania. Komentarz, Warszawa 2011.

Zych M., Mobbing w polskim prawie pracy, Wydawnictwo C.H. Beck, Warszawa 2007.

\section{Akty prawne}

Decyzja Komisji z dnia 11 sierpnia 2011 r. w sprawie upoważnienia Hiszpanii do tymczasowego zawieszenia stosowania art. 1-6 rozporządzenia Parlamentu Europejskiego i Rady (UE) nr 492/2011 w sprawie swobodnego przepływu pracowników wewnątrz Unii w odniesieniu do pracowników rumuńskich, Dz.Urz. UE z 12 sierpnia 2011 r., Nr L 207.

Karta Praw Podstawowych Unii Europejskiej, Dz.Urz. UE. z 2007 r., Nr C 303 z późn. zm.

Pismo Ministra Finansów z dnia 7 czerwca 2002 roku, PB7/033-0136-383/01/ck.

Rozporządzenie Parlamentu Europejskiego i Rady (UE) nr 492/2011 z dnia 5 kwietnia 2011 r. w sprawie swobodnego przepływu pracowników wewnątrz Unii, Dz.Urz. UE z dnia 27 maja 2011 r., Nr L 141.

Traktat o funkcjonowaniu Unii Europejskiej - wersja skonsolidowana, Dz.Urz. UE z 30 marca 2010 r., Nr C 83.

Umowa między Rządem Rzeczypospolitej Polskiej a Rządem Republiki Filipin w sprawie unikania podwójnego opodatkowania i zapobiegania uchylaniu się od opodatkowania w zakresie podatków od dochodu, Dz.U. z 1997 r., Nr 127, poz. 817. 
Umowa między Rządem Rzeczypospolitej Polskiej a Rządem Republiki Indonezji w sprawie unikania podwójnego opodatkowania i zapobiegania uchylaniu się od opodatkowania w zakresie podatków od dochodu, Dz.U. z 1994 r., Nr 46, poz. 187.

Ustawa z dnia 26 lipca 1991 r. o podatku dochodowym od osób fizycznych, tekst jedn. Dz.U. z 2012 r., poz. 361, z późn. zm.

Wyrok Europejskiego Trybunału Sprawiedliwości w sprawie B.N.O. Walrave, L.J.N. Koch przeciwko Association Union cycliste internationale, Koninklijke Nederlandsche Wielren Unie i Federación Española Ciclismo, C-36/74, European Court Reports 1974, s. 1405.

Wyrok Europejskiego Trybunału Sprawiedliwości z dnia 3 lipca 1986, w sprawie Deborah Lawrie-Blum przeciwko Land Baden-Württemberg, C-66/85, European Court Reports 1986, s. 212.

Wyrok Europejskiego Trybunału Sprawiedliwości z dnia 5 lutego 1963 r. w sprawie van Gend \& Loos, 26/62.

Wyrok Naczelnego Sądu Administracyjnego z dnia 18 grudnia 2012 r., II FSK 28/12, publ. CBOSA.

Ustawa z dnia 16.11.2006 r. o zmianie ustawy o podatku dochodowym od osób fizycznych oraz niektórych innych ustaw, Dz.U. z 2006 r., Nr 217, poz. 1588.

Wyrok Trybunału Konstytucyjnego z dnia 8 lipca 2014 r., K 7/13, publ. Z.U. 2014/7A/69.

Interpretacja indywidualna Ministra Finansów z dnia 3 października 2008 r., ITPB2/415692/08/PS.

Interpretacja indywidualna Ministra Finansów z dnia 5 października 2012 r., IPPB4/415$569 / 12-2 / S P$. 